\title{
A new trophic interaction between invasive weed, its biological control agent, and local insects: A case study of Chromolaena odorata
}

\author{
AKHMAD RIZALI ${ }^{1, \bullet}$, MOCHAMMAD SYAMSUL HADI ${ }^{1}$, PUDJIANTO $^{2}$, DAMAYANTI BUCHORI $^{2}$ \\ ${ }^{1}$ Department of Plant Pests and Diseases, Faculty of Agriculture, Universitas Brawijaya. Jl. Veteran, Malang 65145, East Java, Indonesia. \\ Tel./fax.: +62-341-575843. ‘email: arizali@ub.ac.id \\ ${ }^{2}$ Department of Plant Protection, Faculty of Agriculture, Institut Pertanian Bogor. Jl. Raya Dramaga, Kampus IPB Darmaga, Bogor 16680, West Java, \\ Indonesia
}

Manuscript received: 5 March 2019. Revision accepted: 15 March 2019.

\begin{abstract}
Authors. 2019. A new trophic interaction between invasive weed, its biological control agent, and local insects: a case study of Chromolaena odorata. Biodiversitas 20: 1006-1011. Invasive species have been known to cause biotic homogenization. The presence of Chromolaena odorata, an alien invasive weed, in agricultural habitat has outcompeted many crop plants. The presence of alien invasive weed creates a new trophic interaction especially with local herbivores as well as other associate insects. This study was aimed to investigate a new trophic interaction that has been established between $C$. odorata, its introduced biological control agent, and local insects. The research was conducted in various land-use types in both of Arjuno and Bromo mountain landscape. In each landscape, we surveyed the population density of $C$. odorata and its biological control agent (a gall fly, Cecidochares connexa) as well as observed the diversity and abundance of other insects associated with $C$. odorata. Samples were taken along the transect lines at various altitudinal gradients, from 400 to $1100 \mathrm{~m}$ asl. In total, 124 species of insects were found associated with $C$. odorata which include herbivores, parasitoids, and predators. The difference of land-use types affected the population density of $C$. odorata but not its herbivores (i.e. $C$. connexa and aphids). A new association was found between the introduced insect, $C$. connexa and local parasitoids. The field survey also discovered new associations between the invasive weed with local herbivores such as aphids that are found with high abundance. The aphids were found to have a symbiosis interaction with ants such as Anoplolepis gracilipes (invasive species) and Dolichoderus thoracicus. In conclusion, the ecological consequence of the presence of invasive weed species is the shaping of a new trophic interaction with local insects, even with other invasive ant species. This interaction arguably is part of an ecological process that formed an equilibrium interaction which may cause either a negative or positive impact on $C$. odorata.
\end{abstract}

Keywords: Anoplolepis gracilipes, aphid, Arjuno Mountain, Bromo Mountain, Cecidochares connexa

\section{INTRODUCTION}

The presence of alien invasive species in a new habitat causes biotic homogenization through the replacement of local biota by invasive species that can coexist with human (McKinney and Lockwood 2001; Olden et al. 2004). The invasion of exotic weed in an agricultural area can be harmful to crop plants and cause yield loss as a consequence of nutrient competition (Paini et al. 2016). The siam weed, Chromolaena odorata for instance, this weed is originally from tropical America and become prevalent in Asia by early twentieth century (Gautier 1992; Zachariades et al. 2009). This weed causes a negative impact on the native plants via several mechanisms such as altering the soil microbial community (Mangla and Callaway 2008), changing the soil quality (MboukouKimbatsa et al. 2007; Mandal and Joshi 2014), and allelopathy (LiJun et al. 2010; $\mathrm{Hu}$ and Zhang 2013). Therefore, understanding about control management of the siam weed especially in agriculture area is very important to prevent the undesirable effect on crop plants.

An environmentally friendly approach to control the exotic invasive weed is by introducing the natural enemies from the origin area of the invasive weed. This technique is considered due to has several advantages, such as effective to control the weed population by way of the ability to establish and spread to other areas, and also the consideration of control cost which is lower than herbicide application (Schoonhoven et al. 1996; Van Driesche et al. 2010). The famous example of success program was the biological control of Opuntia in Australia (Zimmermann et al. 2009). Opuntia was introduced to Australia as ornamental plants but then become an invasive weed. The population of this weed drastically decreased after introducing its biological control agent, the Argentina moth, Cactoblastis cactorum, an insect herbivore of Opuntia, in 1927-1930 (Schoonhoven et al. 1996; Zimmermann et al. 2009).

However, the biological control programs of exotic weed are sometimes unsuccessful and even have a negative impact on the local community. Biological control with the unspecific host can cause non-target impact through the physical and functional replacement of local species by biological control agents (Pearson and Callaway 2003). The introduction of a new species in a higher trophic level causes the change of community structure of trophic level in the ecosystem (Bellows 2001). Thus, the introduction of exotic species needs a serious monitoring effort especially on their distribution, the existence of local natural enemies, and other species in their new habitat. Without monitoring, 
degradation of biodiversity in an ecosystem is not detected especially in the area that located far from the release point of introduced biological control (Simberloff 1996).

Considering the negative impact of the introduction of biological control agents, it needs a comprehensive study in relation to monitoring and evaluation of the presence of exotic species. The objective of this research were (i) to study the population density of exotic invasive weed, $C$. odorata; its biological control, Cecidochares connexa (Diptera: Tephritidae); and the diversity of its associated (local) insects at different land-use types and various altitudinal gradients in Arjuno and Bromo mountain landscape, and (ii) to investigate a new trophic interaction between $C$. odorata, $C$. connexa, and local insects. The results are expected to provide valuable data as well as basic knowledge about the problems of new species introduction that can cause a non-target impact on local biodiversity (Lonsdale et al. 2001). Thus, it can be used as a recommendation for biodiversity conservation efforts.

\section{MATERIALS AND METHODS}

\section{Research location}

The research was conducted in various land-use types and altitude gradients both in Arjuno and Bromo mountain landscape, East Java, Indonesia. The research area is located in the Bromo Tengger Semeru-Arjuno biosphere reserve that had been designated by UNESCO since 2015 (UNESCO 2015). This biosphere reserve incorporates several mountains, i.e. Mount Bromo (2,392 m asl), Mount Arjuno (3,339 m asl), and Mount Semeru (3,676 m asl) and is home to about 1,025 species of flora and about 158 species of fauna (mammals, birds, and reptiles). The core area of the reserve covered with tropical rainforest and in buffer area included of cultivated and settlement areas.

\section{Transect designation and insect sampling}

In both of Arjuno and Bromo mountain landscape, sampling areas were selected for survey and measure the population of $C$. odorata, $C$. connexa and other insects that associated with $C$. odorata. The field research was conducted from February to April 2018. Sampling areas were the transect lines at various altitudinal gradients, from 400 to $1100 \mathrm{~m}$ asl. The transect lines were started from Malang, Lawang, and Pandaan, toward Mount Arjuno and Mount Bromo. In total 18 transect lines were chosen with nine transect lines in Arjuno mountain landscape and nine transect lines in Bromo mountain landscape. In each transect line, the presence of $C$. odorata was marked and identified the land-use type and the altitude. We categorized the land-use types as agroforest, habitat dominated by trees, open area, rice field, and cropland. The number of clumps, the gall of $C$. connexa, and other associated insects was counted. To study the population of C. connexa and its natural enemies (parasitoids), all galls were collected and brought to the laboratory for rearing and observing the emerging insects. While other associated insects were collected and stored in a plastic vial with $70 \%$ alcohol for identification in the laboratory. Insects were initially identified to order and family level using identification book of Borror et al. (1996) and continued to morphospecies level based on different of morphological character (Lattke 2000). For parasitoid wasps, identification was conducted using reference of Goutlet and Huber (1993), while for ants were identified to genera level using reference of Bolton (1994).

\section{Data analysis}

The difference of population density of $C$. odorata, $C$. connexa, and other insects between land-use types was analyzed using analysis of variance (ANOVA). The relationship between altitudinal gradients and population density of $C$. odorata, $C$. connexa, and other insects was analyzed using Pearson correlation for linear model and for the non-linear model was used the generalized additive model (GAM) using a Poisson distribution. The relationship between $C$. odorata, $C$. connexa, its parasitoid, other herbivores, and ants was analyzed using the linear mixed-effects model (LME) using maximum likelihood (ML) (Zuur et al. 2009). Different landscape/region (mountain area) and land-use were included as a random factor. Based on the LME result, an interaction diagram was developed to illustrate the relationship between the most abundant species. The significant effect of the fixed effects was analyzed using Wald tests. All analyses were performed using $\mathrm{R}$ statistical software ( $\mathrm{R}$ Core Team 2018), utilized the package of nlme for LME analysis (Pinheiro et al. 2017), the package of MASS for stepwise backward selection (Venables and Ripley 2002) and the package of mgcv for GAM (Wood 2011).

\section{RESULTS AND DISCUSSION}

\section{Insect diversity that associated with $\boldsymbol{C}$. odorata}

In total, we found 124 species and 13,855 individual of insects that were associated with $C$. odorata with the most abundant was Aphis spp. (Hemiptera: Aphididae) (Table 1). In Arjuno landscape, we recorded 74 species and 6400 individual while in Bromo landscape, we found 89 species and 7455 individual with 39 species were found in both locations. The most dominant herbivores were $C$. connexa (735 individual) and Aphis sp1 (9656 individual), while predators were Anoplolepis gracilipes (497 individual) and Dolichoderus thoracicus (1551 individual) that were found symbiosis with Aphis spp.

The diversity of insects associated with $C$. odorata in Arjuno and Bromo landscape were lower than in the native area of C. odorata. Cruttwell (1974) reported approximately 225 herbivore insects and mites associated with $C$. odorata, mainly in Trinidad and other areas of its native range. $C$. connexa which was recorded as herbivore of $C$. odorata in Trinidad, Mexico, and Bolivia (Cruttwell 1974), was also found in Arjuno and Bromo landscape. Surprisingly, as local herbivore insects, Aphis spp. can be associated with $C$. odorata. As a herbivore, aphids attack in the shoot tips of the $C$. odorata, while $C$. connexa uses the shoot tips for laying eggs and the larvae develop within galls at the nodes of the plant. 
As introduced species, $C$. connexa was imported from Colombia to Indonesia and was released in North Sumatra in 1995 and later on other Indonesian islands (Tjitrosemito 1998; McFadyen et al. 2003). This tephritid fly can be established easily from small founder populations, i.e. about 100 pairs were released at each of several sites across Indonesia (Tjitrosemito 1998). Once established, the population of $C$. connexa can rapidly build up and spread. In Sumatra, $C$. connexa was reported spread over $200 \mathrm{~km}$ within 5 years following release (Desmier de Chenon et al. 2002).

\section{Effect of land-use type and altitude on $C$. odorata, $C$. connexa, and their associate insects}

We found that the population density of $C$. odorata was significantly different between land-use types $\left(\mathrm{F}_{4,58}=\right.$ $4.775, \mathrm{P}=0.002$ ) and not significantly different between Arjuno and Bromo landscape $\left(\mathrm{F}_{1,58}=2.589, \mathrm{P}=0.113\right)$ (Figure 1.A). While for its herbivore (i.e., C. connexa and Aphis spp.), their abundance did not differ between landuse types $(\mathrm{P}>0.05)$ as well as between landscapes $(\mathrm{P}>0.05)$ (Figure 1.B and 1.C).

We did not find the linear relationship between altitude and population of $C$. odorata, $C$. connexa, and their associated insects, except for Aphid. Based on correlation analysis, the abundance of Aphis spp. had a negative correlation with altitude $(\mathrm{r}=-0.259, \mathrm{P}=0.038)$. However, based on the GAM showed the non-linear relationship between altitude and $C$. odorata (deviance $=17.2 \%$, $\mathrm{P}<0.001), C$. connexa (deviance $=10.7 \%, \mathrm{P}<0.001$ ), as well as Aphid (deviance $=31.8 \%, \mathrm{P}<0.001$ ). The highest abundance of $C$. odorata, $C$. connexa, and Aphis spp. was found in the range of altitude between 500 to $700 \mathrm{~m}$ asl (Figure 2).

Chromolaena odorata was reported tolerant in the subtropical and tropical region and found establish and dominant in disturb area, grassland, and plantation, and highly spread due to ability and distribution efficiency (Zachariades et al. 2009). In its native range, $C$. odorata is a common weed species that grow from the coast to an altitude of 1000-1500 m asl (McFadyen 1991), although it has been collected at a maximum altitude of almost $3000 \mathrm{~m}$ asl (Gautier 1992). C. odorata is suitable to grow in sunny and open areas such as roadsides, abandoned fields, pastures, and disturbed forests, but this weed also tolerates semi-shade conditions (Zachariades et al. 2009). C. odorata is not bloomed under the shaded conditions of undisturbed forest or in closely planted and well-established orchards. In Asia, C. odorata can be found up to $1000 \mathrm{~m}$ asl (McFadyen 1989) and has been recorded at $2000 \mathrm{~m}$ asl in Cameroon (Timbilla 1998).

Table 1. Abundance $(\mathrm{N})$ and species richness (S) of insects that associated with Chromolaena odorata collected from Arjuno and Bromo landscape

\begin{tabular}{lrrrrrrll}
\hline \multicolumn{1}{c}{ Order } & \multicolumn{2}{c}{ Arjuno } & \multicolumn{2}{c}{ Bromo } & \multicolumn{2}{c}{ Total } & \multirow{2}{*}{ Role } & Dominant species \\
\hline Araneae & N & S & \multicolumn{1}{c}{ N } & S & \multicolumn{1}{c}{ N } & S & \\
Coleoptera & 13 & 11 & 19 & 17 & 32 & 25 & Predator & \\
Diptera & 53 & 17 & 37 & 15 & 90 & 27 & Herbivore \& Predator & C. connexa \\
Hemiptera & 431 & 9 & 333 & 10 & 764 & 15 Herbivore & Aphis sp. 1 \\
Hymenoptera & 4,366 & 9 & 5,706 & 10 & 10,072 & 13 Herbivore & D. thoracicus, A. gracilipes \\
$\quad$ Ants (Formicidae) & 1,514 & 16 & 1,318 & 20 & 2,832 & 25 & Predator & \\
$\quad$ Non-ants & 14 & 4 & 8 & 6 & 22 & 6 Parasitoid & \\
Lepidoptera & 1 & 1 & 3 & 1 & 4 & 2 Herbivore & \\
Mantodea & 1 & 1 & 9 & 1 & 10 & 1 Predator & \\
Orthoptera & 7 & 6 & 22 & 9 & 29 & 10 Herbivore & \\
Total & 6,400 & 74 & 7,455 & 89 & 13,855 & 124 & & \\
\hline
\end{tabular}
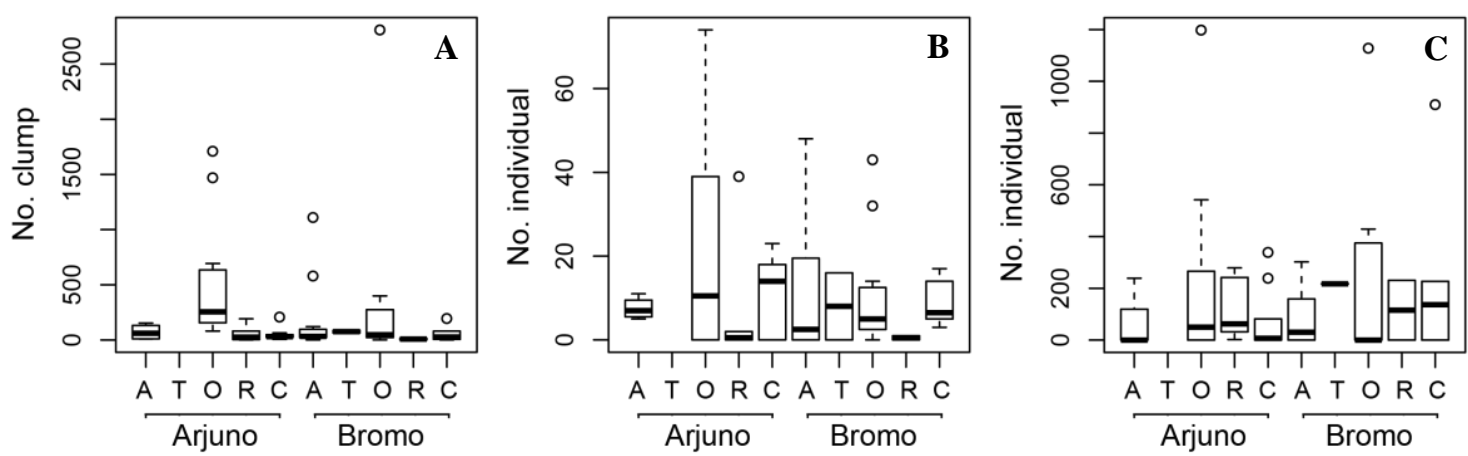

Figure 1. The population density of A. Chromolaena odorata, B. Cecidochares connexa, and C. Aphis spp., in different land-use types in Arjuno and Bromo mountain landscape. The letters indicate land-use type, A: agroforest, T: habitat dominated by trees, O: open area, $\mathrm{R}$ : rice field and C: cropland 

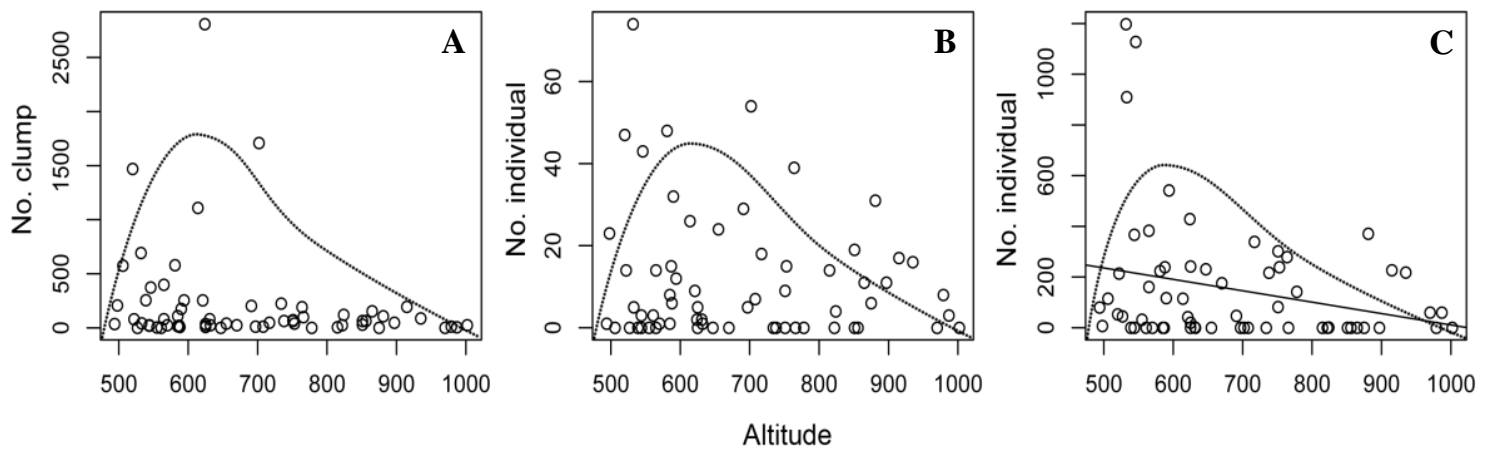

Figure 2. The relationship between altitude ( $\mathrm{m}$ asl) and the population density of A. Chromolaena odorata, B. Cecidochares connexa, and C. Aphid sp. Dot curve line indicates a non-linear relationship based on generalized additive models (GAM) and the straight line indicates a linear relationship based on Pearson's correlation

Cecidochares connexa was reported effective to control C. odorata, particularly in areas at lower elevations with a short dry season (McFadyen et al. 2003). In suitable condition, galls of $C$. connexa can be found hundreds per plant and cause $C$. odorata to become prematurely moribund with few flowers or seeds, or die back (Desmier de Chenon et al. 2002). The galls have been shown to act as a resource sink and to slow the growth of the plant (Cruz et al. 2006). In this research, the population density of $C$. connexa was lower in higher elevation. Previous research also found that $C$. connexa was less effective in higherelevation, cooler areas and those with a longer dry season, as fewer generations are produced per annum and therefore populations build up slowly (Zachariades et al. 2009). Besides the altitude, parasitism by parasitoids can also reduce the effectiveness of $C$. connexa. Although, parasitism and predation levels of $C$. connexa was remained low, although up to $50 \%$ parasitism was recorded at one site in Java (McFadyen et al. 2003).

A similar pattern is shown for aphids which also related to altitude gradient that the density was found higher in certain altitude. However, aphid density was also found tends to decrease with increasing altitude. The result is similar to previous research that also found the negative relationship between aphid density with altitude gradient (Johnson and Penman 1951; Zhang et al. 2015). Beside altitude, aphid density was also related to ant density especially $A$. gracilipes $(\mathrm{r}=0.368, \mathrm{P}=0.003)$ and $D$. thoracicus $(\mathrm{r}=0.269, \mathrm{P}=0.031)$. Previous research also showed the relationship between aphid density and ant density (Zhang et al. 2015). In this research, we did not investigate the effect of aphids on the growth of $C$. odorata but presumably has a similar effect with $C$. connexa. Research by Watanabe et al. (2018) found that the parasitism of aphid, Macrosiphoniella yomogicola, in the mugwort (Artemisia montana) did not affect the host plant growth, but significantly decreased the number of inflorescences.

\section{A new trophic interaction between $C$. odorata, $C$. connexa, and other insects}

Based on the LME, we found the complex interaction between $C$. odorata, its herbivore ( $C$. connexa) and other insects. $C$. connexa has a positive direct association with $C$. odorata, while Aphis spp. and other herbivore insects also have a direct association with $C$. odorata. As an introduced natural enemy of $C$. odorata, $C$. connexa showed has a direct association with local parasitoids and indirect association with Aphis spp., D. thoracicus, and A. gracilipes (Figure 3 ).

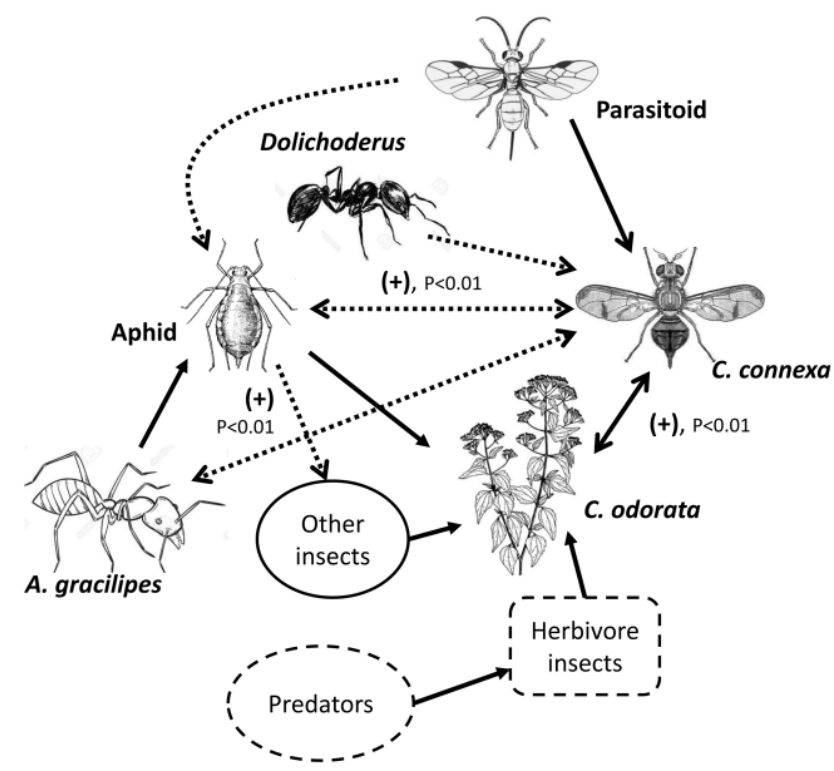

Figure 3. A new trophic interaction between $C$. odorata, $C$. connexa, and other insects. The LME analysis was used to investigate the interactions which are depicted with dot arrow line (indirect interaction) and sign (+) indicate a positive effect. Direct interaction is based on visual observation in the field and depicted with a solid arrow line. Box with dash line are not included in the LME analysis but have the interaction based on the visual observation 
The network revealed a new trophic interaction between $C$. odorata with local insects. Even, invasive ant species, $A$. gracilipes (McGlynn 1999) was also indirectly associated with this weed through symbiosis with local herbivore insects (Aphis spp.). This complex interaction seems to have a positive or negative effect on $C$. odorata and provide ecosystem services or disservices. However, it is argued that the interactions support the presence and growth of $C$. odorata which cause a negative effect on crop plants. A study by Vandermeer et al. (2010) in organic coffee also revealed that the ecological complexity shaped from the interaction between pests, diseases, ants and other insects provided ecosystem service and support the growth of the coffee plant.

We detected that the occurrence of the invasive weed, $C$. odorata was followed by its herbivores and the patterns were similar between landscapes, but dissimilar between land-use types. It indicated the difference of adaptation process between $C$. odorata and its natural enemies $(C$. connexa), and it revealed the presence of $C$. connexa did not significantly affect the control of $C$. odorata. Yet the introduction of $C$. connexa shaped new interactions with local parasitoids as well as other insects. This suggested that the presence of $C$. connexa in its new habitat cause non-target impact and arguably support on ecosystem disservices (Van Driesche and Hoddle 2016). Therefore, we suggest considering the importance of indirect effect before introducing natural enemies to control invasive weeds as a consequence of new interaction between natural enemies with local plants, local herbivores as well as local natural enemies (Lonsdale et al. 2001). In conclusion, research on the evaluation after the release of natural enemies to control invasive weed should not only be conducted after the first year release, instead, it also needs to include the long-term monitoring to understand the longterm effect of introduction (Hopper 2001). As a consequence of the presence of invasive species in the new habitat, a new complex trophic interaction is formed. This interaction is likely a part of an ecological process that formed an equilibrium interaction which may cause either a negative or positive impact on $C$. odorata.

\section{ACKNOWLEDGMENTS}

We give thanks to Prita Amalia dan Bagas Prima Yudhanta for helping during field observations and laboratory activities. This research project was funded by the Faculty of Agriculture, University of Brawijaya, Malang, Indonesia and the Ministry of Research, Technology, and Higher Education of the Republic of Indonesia.

\section{REFERENCES}

Bellows TS. 2001. Restoring population balance through natural enemy introductions. Biological Control 21: 199-205.

Bolton B. 1994. Identification Guide to the Ant Genera of the World, Harvard University Press, Cambridge.
Borror D, Triplehorn CH, Johnson NF. 1996. An Introduction to the Study of Insects, 6th ed. Saunders College Publishing, Ohio, USA.

Cruttwell RE. 1974. Insects and mites attacking Eupatorium odoratum in the neotropics: An annotated list of the insects and mites recorded from Eupatorium odoratum L., with a key to the types of damage found in Trinidad. Technical Bulletin of the Commonwealth Institute of Biological Control 17: 87-125.

Cruz ZT, Muniappan R, Reddy GVP. 2006. Establishment of Cecidochares connexa (Diptera: Tephritidae) in Guam and its effect on the growth of Chromolaena odorata (Asteraceae). Annals of the Entomological Society of America 99: 845-850.

Desmier de Chenon R, Sipayung A, Sudharto P. 2002. A decade of biological control against Chromolaena odorata at the Indonesian Oil Palm Research Institute in Marihat. In: Zachariades C, Muniappan R, Strathie LW (Eds.), Proceedings of the Fifth International Workshop on Biological Control and Management of Chromolaena odorata. pp. 46-52. ARC-PPRI, Pretoria, South Africa.

Gautier L. 1992. Taxonomy and distribution of a tropical weed, Chromolaena odorata (L.) R. King and H. Robinson. Candollea 47: 645-662.

Goutlet H, Huber JT. 1993. Hymenoptera of the World: an Identification Guide to Families, Centre for Land and Biological Resources Research, Ottawa, Canada.

Hopper KR. 2001. Research needs concerning non-target impacts of biological control introductions. In: Wajnberg E, Scott JK, Quimby PC (eds.). Evaluating Indirect Ecological Effects of Biological Control. CABI Publishing, Wallingford.

Johnson CG, Penman HL. 1951. Relationship of aphid density to altitude. Nature 168: 337-338

Lattke JE. 2000. Specimen processing: building and curating an ant collection. In: Agosti D, Majer JD, Alonso LE, Schultz TR (eds.). Ants: Standard Methods for Measuring and Monitoring Biodiversity. Smithsonian Institution Press, Washington, DC.

Lonsdale WM, Briese DT, Cullen JM. 2001. Risk analysis and weed biological control. In: Wajnberg E, Scott JK, Quimby PC (Eds.), Evaluating Indirect Ecological Effects of Biological Control. CABI Publishing, Wallingford, UK.

McFadyen REC. 1989. Siam weed: a new threat to Australia's north. Plant Protect Quart 4: 3-7.

McFadyen REC. 1991. The ecology of Chromolaena odorata in the neotropics. In: Muniappan R, Ferrar P (eds.). Proceedings of the Second International Workshop on Biological Control of Chromolaena odorata. BIOTROP Special Publication, Bogor.

McFadyen REC, Desmier de Chenon R, Sipayung A. 2003. Biology and host specificity of the Chromolaena stem gall fly, Cecidochares connexa (Macquart) (Diptera: Tephritidae). Australian J Entomol 42: 294-297.

McGlynn TP. 1999. The worldwide transfer of ants: geographical distribution and ecological invasions. J Biogeogr 26: 535-548.

McKinney ML, Lockwood JL. 2001. Biotic homogenization: a sequential and selective process. In: Lockwood JL, McKinney ML (eds.), Biotic Homogenization. Kluwer Academic, New York.

Olden JD, Poff NL, Douglas MR, Douglas ME, Fausch KD. 2004. Ecological and evolutionary consequences of biotic homogenization. Trends Ecol Evol 19: 18-24.

Paini DR, Sheppard AW, Cook DC, Barro PJD, Worner SP, Thomas MB. 2016. Global threat to agriculture from invasive species. Proc Natl Acad Sci USA 113: 7575-7579.

Pearson DE, Callaway RM. 2003. Indirect effects of host-specific biological control agents. Trends in Ecology \& Evolution 18: 456461.

Pinheiro J, Bates D, DebRoy S, Sarkar D, R Core Team. 2017. nlme: Linear and Nonlinear Mixed Effects Models. R package version 3.1131. R Foundation for Statistical Computing, Vienna, Austria.

R Core Team. 2018. R: A Language and Environment for Statistical Computing. R Foundation for Statistical Computing, Vienna, Austria.

Schoonhoven LM, Jermy T, van Loon JJA. 1996. Insect-plant Biology: From Physiology to Evolution. Chapman \& Hall, London.

Simberloff D. 1996. How risky of biological control? Ecology 77: 19651974.

Timbilla JA. 1998. Effect of biological control of Chromolaena odorata on biodiversity: a case study in the Ashanti region of Ghana. In: Ferrar P, Muniappan R, Jayanth KP (eds.). Proceedings of the Fourth International Workshop on the Biological Control and Management of Chromolaena odorata. Agricultural Experiment Station, University of Guam, Mangilao, Guam. 
Tjitrosemito S. 1998. Integrated management of Chromolaena odorata: emphasizing the classical biological control. Biotropia 11: 9-21.

UNESCO. 2015. Biosphere Reserves in Indonesia: Bromo Tengger Semeru-Arjuno. http://www.unesco.org

Van Driesche R, Hoddle M. 2016. Non-target effects of insect biocontrol agents and trends in host specificity since 1985. CAB Reviews 11: 166.

Van Driesche RG, Carruthers RI, Center T, Hoddle MS, Hough-Goldstein J, Morin L, Smith L, Wagner DL, Blossey B, Brancatini V, Casagrande R, Causton CE, Coetzee JA, Cudam J, Ding J, Fowler SV, Frank JH, Fuester R, Goolsby J, Grodowitz M, Heard TA, Hill MP, Hoffmann JH, Huber J, Julien M, Kairo MTK, Kenis M, Mason P, Medal J, Messing R, Miller R, Moore A, Neuenschwander P, Newmanaa R, Norambuena H, Palmer WA, Pemberton R, Panduro AP, Pratt PD, Rayamajhi M, Salom S, Sands D, Schooler S, Schwarzländer M, Sheppard A, Shaw R, Tipping PW, van Klinken RD. 2010. Classical biological control for the protection of natural ecosystems. Biol Contr 54: S2-S33.

Vandermeer J, Perfecto I, Philpott S. 2010. Ecological complexity and pest control in organic coffee production: uncovering an autonomous ecosystem service. Bioscience 60: 527-537.
Venables WN, Ripley BD. 2002. Modern Applied Statistics with S. 4th ed. Springer, New York.

Watanabe S, Murakami Y, Hasegawa E. 2018. Effects of aphid parasitism on host plant fitness in an aphid-host relationship. PLoS ONE 13: e0202411. DOI: 10.1371/journal.pone.0202411.

Wood SN. 2011. Fast stable restricted maximum likelihood and marginal likelihood estimation of semiparametric generalized linear models. J R Stat Soc B 73: 3-36.

Zachariades C, Day M, Muniappan R, Reddy GVP. 2009. Chromolaena odorata (L.) King and Robinson (Asteraceae). In: Muniappan R, Reddy GVP, Raman A (Eds.), Biological Control of Tropical Weeds Using Arthropods. Cambridge University Press, Cambridge, UK.

Zhang S, Zhang Y, Ma K. 2015. Mutualism with aphids affects the trophic position, abundance of ants and herbivory along an elevational gradient. Ecosphere 6: 253.

Zimmermann H, Moran C, Hoffmann J. 2009. Invasive cactus species (Cactaceae). In: Muniappan R, Reddy GVP, Raman A (eds.). Biological Control of Tropical Weeds Using Arthropods. Cambridge University Press, Cambridge, UK.

Zuur AF, Ieno EN, Walker NJ, Saveliev AA, Smith GM. 2009. Mixed Effects Models and Extensions in Ecology with R. Springer, New York. 